\title{
Pengaruh Tingkat Pendidikan, Motivasi Kerja, Dan Disiplin Kerja Terhadap Kinerja Guru di SMPN I Kecamatan Pangkalan Koto Baru Kabupaten 50 Kota
}

\author{
YOGIE RAHMAT \\ Sekolah Tinggi Ilmu Ekonomi Riau \\ Jln. HR. Subrantas 57 Panam Pekanbaru 28293 Telp. (0761) 63237 \\ E.mail : yogierahmat400@gmail.com
}

\begin{abstract}
Performance is affected by various factors, associated with labor itself, as well other factors, as educational level, work motivation, work discipline, and others. Education can affect the performance of teachers, because education can shape one's mindset and increase knowledge, motivation is also a very important influential factor in determining a person's behavior. Discipline in organizational life is intended for all employees in the organization is willing to voluntarily abide by and obey all the rules and regulations applicable without any coercion. This study aims to look at how much influence the level of education, motivation and discipline in the SMPN 1 Kecamatan Pangkalan Koto Baru. Population and sample in this research are as many as 33 teachers in SMPN 1 Kecamatan Pangkalan Koto Baru, This research was conducted in December 2016, is address street Sumbar-Riau, Kecamatan Pangkalan Koto Baru, Kabupaten 50 Kota, Sumatera Barat. The results of the study that in partial Education Level but not significant positive effect on the performance of teachers with a level significantly greater than the coefficient $\alpha$ is $(0.722>$ 0.05), so that the initial hypothesis "Denied", while for the variable Work Motivation and Work Discipline showed a positive and significant impact on teacher performance level is significantly smaller than the coefficient $\alpha$, is working motivation $(0.000>0.05)$ and Work Discipline $(0.000<0.05)$, so the hypothesis is "Accepted". While simultaneously variable levels of education, motivation Work and Work Discipline positive and significant impact on teacher performance with the value of T counted by 89610 and 0000 sebesat significantly smaller than $\alpha=0: 05$, so the hypothesis is "Accepted".
\end{abstract}

Keywords: Education, Motivation, Discipline, Teacher Performance.

Keunggulan suatu bangsa tidak lagi bertumpu pada kekayaan alam melainkan pada keunggulan sumber daya manusia (SDM) yaitu tenaga terdidik yang mampu menjawab tantangan-tantangan dengan sangat cepat sebagai upaya menghadapi tantangan era globalisasi disegala bidang. Dengan kemajuan teknologi yang didukung dengan Sumber Daya Manusia berkualitas mempunyai posisi penting dalam perusahaan dan mempunyai peranan yang sangat dominan terhadap kinerja perusahaan sehingga perusahaan harus mampu mengelola Sumber Daya Manusia secara efektif dan efisien. Dengan demikian Sumber Daya Manusia yang dikelola oleh organisasi harus mampu menunjang kinerja yang baik sehingga perusahaan dapat mencapai tujuan yang diinginkan. Begitu juga dengan dunia pendidikan, untuk menciptakan siswa yang berkopentesi, tenaga pendidik harus memiliki keterampilan dan pengetahuan tata cara mendidik dengan baik. Sehingga hasil lulusan akan menjadi tolak ukur dari kopentensi para pendidik.

Guru merupakan kunci dalam peningkatan mutu pendidikan danmereka berada di titik sentral dari setiap usaha reformasi pendidikan yang diarahkan pada perusahan-perubahan kualitatif. Setiap usaha peningkatan mutu pendidikan seperti perubahan kurikulum, pengembangan metode-metodemengajar, penyediaan sarana dan prasarana akan berarti apabila melibatkan guru (Saudagar dan Idrus dalam Nuruni, 2014: 1).

Tingkat pendidikan dapat mempengaruhi kinerja guru, karena pendidikan dapat membentuk pola pikir 
seseorang dan menambah ilmu pengetahuan. Perbedaan tingkat pendidikan seseorang dapat menimbulkan perbedaan dalam berfikir dan bertindak. Tingkat keilmuan yang dimiliki oleh seorang guru sangat mempengaruhi dalam menjalankan tugasnya sebagai pendidik yang bertugas mentransfer ilmu kepada para siswa. Selain itu, cara bersikap seorang yang berpendidikan akan berpikir terlebih dahulu sebelum bertindak. Hal ini berpengaruh terhadap bagaimana seorang guru mengemban amanah dengan baik dan menjaga kinerjanya.

Dalam peningkatan kinerja guru, motivasi juga merupakan faktor yang berpengaruh. Motivasi merupakan salah satu aspek yang sangat penting dalam menentukan perilaku seseorang, termasuk perilaku kerja. Untuk memotivasi seseorang diperlukan pemahaman tentang bagaimana proses terbentuknya motivasi. Motivasi diartikan sebagai faktor-faktor yang mengarahkan dan mendorong perilaku atau keinginan seseorang untuk melakukan suatu kegiatan yang dinyatakan dalam bentuk usaha yang keras atau lemah. Faktor-faktor itu disebut dengan motivasi, sebagai tujuan yang diinginkan yang mendorongorang berperilaku tertentu. Sehingga motivasi sering diartikan dengan keinginan, tujuan, kebutuhan, atau dorongan, dan sering dipakai secara bergantian untuk menjelaskan motivasi seseorang. Motif yang sangat kuat akan membentukusaha yang keras berdasarkan kompleksitas faktor motivasional.

Penerapan disiplin dalam kehidupan organisasi ditujukan agar semua pegawai yang ada dalam organisasi bersedia dengan suka rela mematuhi dan mentaati segala peraturan dan tata tertib yang berlaku tanpa ada paksaan. Dalam kaitan ini disiplin sangat diperlukan dalam suatu organisasi, karena untuk mencapai tujuan dan sasaran yang telah ditetapkan. Pegawai yang disiplin akan mentaati semua norma-norma dan nilai-nilai serta aturan yang telah ditetapkan dalam organisiasi.
Masalah yang sering dihadapi dan behubungan dengan kinerja diantaranya adalah pada hasil kerja guru masih ada yang mengalami penurunan, pencapaian target kerja masih mengalami hambatan, standar kerja juga masih ada yang tidak sesuai dengan harapan.

Selain dari pengumpulan kinerja guru juga dapat dilihat dari keberhasilan siswa mencapai KKM yang ditentukan oleh sekolah.

setiap mata pelajaran masih banyak siswa yang tidak tuntas KKM (remedial). Hal ini kemungkinan disebabkan kurang maksimalnya kinerja guru SMPN I Pangkalan Masalah yang dihadapi institusi berhubungan dengan kepribadian diantaranya adalah masih adanya hambatan dalam pemecahan masalah dalam bekerja, masih ada guru yang belum mampu bekerja dengan baik walau sudah termotivasi dari rekan kerja maupun kepala sekolah, dan ada keterampilan guru yang tidak sesuai dengan kondisi kebutuhan kerja. Selain itu masih ada terjadi pemakaian waktu luang dalam bekerja yang berlebihan.

Menurut Mangkunegara (2015:2) Manajemen sumber daya manusia merupakan suatu perencanaan, pengorganisasian, mengkoordinasikan, pelaksanaan, dan pengawasan terhadap pengadaan, pengembangan, pemberian balas jasa, pengintegrasian, pemeliharaan dan pemisahkan tenaga kerja dalam rangka mencapai tujuan organisasi.

Manajemen sumber daya manusia pada umumnya untuk memperoleh tingkat perkembangan karyawan yang setinggitingginya, hubungan kerja yang serasi diantara karyawan dan penyatupaduan sumber daya manusia secara efektif atau tujuan efisiensi dan kerja sama hingga diharapkan akan meningkatkan produktifitas kerja (Sunyoto, 2012: 1)

Menurut Ihsan dalam Nuruni (2014: 14) Tingkat pendidikan seringkali disamakan dengan jenjang pendidikan karena kedua kata ini memiliki makna yang sama. Jenjang pendidikan adalah

$$
\text { p.ISSN: } 2407-800 X \quad \text { e.ISSN: 2541-4356 }
$$


tahap pendidikan yang ditetapkan berkelanjutan, yang ditetapkan berdasarkan tingkat perkembangan peserta didik, tingkat kerumitan bahan pengajaran, dan cara penyajian bahan pengajaran. Pendidikan pada hakekatnya adalah upaya-upaya untuk mengadakan perubahan. Dalam prosesnya, untuk mencapai tujuan pendidikan dibutuhkan tenaga, waktu dan seperangkat informasi yang harus disampaikan pada jangka waktu tertentu.

Pengertian motivasi ditafsirkan secara berbeda-beda oleh para ahli sesuai dengan tempat dan keadaan masingmasing, namun pada hakekatnya terdapat persamaan prinsip. Motivasi dapat juga diartikan sebuah jawaban mengapa seseorang bersedia melakukan pekerjaan tertentu. Motivasi menyangkut reaksi berantai yaitu dari adanya kebutuhan yang dirasakan, kemudian timbul keinginan atau sasaran yang hendak dicapai dan mencari usaha untuk mencapai sasaran, serta berakhir dengan pemuasan (Handono, 2015: 1075).

Menurut Sugiyono dan Rahadhini (2011: 3) di dalam jurnal Manajemen sumber daya manusia menyebutkan bahwa "Motivasi kerja merupakan suatu kekuatan yang ada dalam diri seseorang yang dapat mengarahkan perilaku untuk melakukan suatu kegiatan sesuai tujuan yang ingin dicapai. Kekuatan ini dapat dikembangkan oleh individu sendiri atau kekuatan dari luar. Di lingkungan kerja, motivasi karyawan turut mempengaruhi hasil kinerjanya, baik secara positif atau negatif. Apabila karyawan mempunyai motivasi kerja yang baik, pada umumnya akan dapat melakukan pekerjaannya denganbaik pula. Lingkungan kerja secarakonseptual adalah situasi atau keadaan lingkungan tempat karyawan bekerja, baik berupa lingkungan fisik maupun non fisik yang dapat mempengaruhi semangat kerja".

Disiplin yang merupakan suatu kegiatan untuk meningkatkan kinerja menyangkut penerapan kekuasaan dari pimpinan bergantung pada budaya dari negara atau organisasinya. Dalam budaya

Jurnal Daya Saing (Vol. 4, No. 1 Feb 2018)
Indonesia kata "kekuasaan" seringkali mempunyai konotasi negatif. 1stilah ini nampaknya secara erat dikaitkan dengan gagasan paksaan terhadap orang lain dan menampilkan bentuk hasrat untuk menanamkan kesan pada orang lain melalui kata-kata atau tindakan, usaha untuk mempengaruhi dalam menaikkan prestasi untuk kebaikan bersama, kepedulian akan reputasidan kemampuan untuk secara spontan memberi dukungan atau nasehat (Handono, 2015: 1075). Menurut Singodimedjo dalam Sutrisno (2014: 86) menyatakan disiplin adalah sikap kesediaan seseorang yang mematuhi dan menaati norma-norma peraturan yang berlaku disekitarnya.

Kinerja merupakan hasil kerja yang dapat dicapai oleh seseorang atau sekelompok orang dalam suatu organisasi, sesuai dengan wewenang dan tanggung jawab masing-masing, dalam rangka mencapai tujuan organisasi bersangkutan secara legal, tidak melanggar hokum dan sesuai dengan moral maupun etika (Sedermayanti, 2015: 260). Menurut Sunyoto (2012: 18) kinerja atau prestasi kerja adalah sesuatu hasil kerja yang dicapai seseorang dalam melaksakan penyelesaian pekerjaan yang dibebankan kepadanya.

\section{METODE}

Lokasi penelitian ini adalah SMPN I Pangkalan dengan alamat Jalan lintas Sumbar-Riau, Kecamatan Pangkalan Koto Baru, Kabupaten 50 Kota, Sumatera Barat.

Metode Deskriptif. Adalah analisis yang menekankan pada pembahasan datadata dan subjek penelitian dengan menyajikan data-data secara sistematik dan tidak menyimpulkan hasil penelitian.

Metode Kuantitatif, Adalah metode penelitian yang menunjukkan kepada riset yaitu dalam bentuk rumusan-rumusan. Rumusan-rumusan yang penulis gunakan dalam menganalisis atau mengukur pengaruh motivasi terhadap kinerja.

Sumber data dalam penelitian ini adalah data Primer merupakan sumber data

p.ISSN: $2407-800 X \quad$ e.ISSN: 2541-4356 
yang diperoleh secara langsung dari SMPN I Pangkalan. Dan data Skunder adalah data yang diperoleh penulis dalam bentuk sudah jadi, tabel-tabel, daftar dan gambar yang diperoleh dari buku-buku ilmiah yang berhubungan dengan penelitian.

Populasi dalam penelitian ini adalah seluruh guru SMPN I Pangkalan yang berjumlah 33 orang. Sampel penelitian ini adalah seluruh guru SMPN I Pangkalan yang berjumlah 33 orang, sebagaimana jumlah populasi. Teknik pengumpulan data yang akan dilakukan dalam penelitian ini adalah: Interview, Yaitu melakukan wawancara langsung dengan guru SMPN I Pangkalan. Kuesioner, yaitu merupakan pengumpulan data yang dilakukan dengan cara memberi pertanyaan tertulis kepada responden untuk dijawab

Untuk mengetahui besarnya pengaruh tingkat pendidikan, motivasi, dan disiplin kerja terhadap kinerja guru, maka dilakukan analisis regresi.

\section{HASIL}

Dari hasil penelitian dapat diketahui bahwa: Tingkat siginifikan $(0,722>0,05)$, artinya secara parsial tidak ada pengaruh positif yang signifikan antara tingkat pendidikan dengan kinerja guru. Dengan demikian Ho di terima dan $\mathrm{Ha}$ di tolak. Diduga tingkat pendidikan secara parsial tidak berpengaruh positif yang signifikan terhadap Kinerja guru di SMPN 1 Pangkalan. Tingkat siginifikan $(0,000<0,05)$, artinya secara parsial ada pengaruh positif dan signifikan antara motivasi kerja dengan kinerja guru. Dengan demikian Ho di tolak dan Ha di terima. Diduga motivasi kerja secara parsial berpengaruh positif dan signifikan terhadap Kinerja guru di SMPN 1 Pangkalan.

Tingkat siginifikan $\quad(0,000<0,05)$, artinya secara parsial ada pengaruh positif dan signifikan antara disiplin kerja dengan kinerja guru. Dengan demikian Ho di tolak dan $\mathrm{Ha}$ di terima. Diduga disiplin kerja secara parsial berpengaruh positif dan signifikan terhadap Kinerja guru di SMPN 1 Pangkalan.

\section{PEMBAHASAN}

Berdasarkan hasil penelitian yang telah dilakukan, maka penulis dapat mengimplikasikan hal-hal sebagai berikut :

Tidak terdapat pengaruh yang signifikan variabel tingkat pendidikan terhadap kinerja guru pada SMPN 1 Pangkalan. Dimana diperoleh tingkat signifikan lebih besar dari alpha $(0,722>0,05)$. Artinya tingkat pendidikan yang baik berpengaruh meningkatkan Kinerja Guru pada SMPN 1 Pangkalan. Selain itu juga didapat nilai koefisien dari variabel tingkat pendidikan sebesar 0,034. Artinya jika terjadi peningkatan nilai tingkat pendidikan sebesar satu satuan maka akan meningkatkan Kinerja Guru sebesar 0,034 satuan. Demikian juga sebaliknya jika terjadi penurunan nilai tingkat pendidikan sebesar satu satuan maka akan menurunkan Kinerja Guru sebesar 0,034 satuan. Penelitian ini tidak sejalan dengan penelitian yang dilakukan oleh Bonifasius (2015), yang menyatakan bahwa tingkat pendidikan berpengaruh signifikan sebesar 0,556 terhadap kinerja pegawai.

Terdapat pengaruh positif dan signifikan variabel motivasi kerja terhadap kinerja guru pada SMPN 1 Pangkalan. Dimana diperoleh tingkat signifikan lebih kecil dari alpha $(0,000<0,05)$. Maka dari itu terbukti bahwa motivasi kerja berfungsi untuk meningkatkan kinerja guru, Artinya, secara parsial ada pengaruh yang positif dan signifikan antara Motivasi Kerjaterhadap Kinerja Guru. Ini berarti Motivasi Kerjayang baik dapat meningkatkan Kinerja guru pada SMPN 1 Pangkalan.Selain itu juga didapat nilai koefisien regresi dari variabel Motivasi Kerjasebesar 1,126 Artinya jika terjadi peningkatan nilai Motivasi Kerjasebesar satu satuan maka akan meningkatkan Kinerja Guru sebesar 1,126 satuan. Demikian juga sebaliknya jika terjadi penurunan nilai Motivasi Kerjasebesar satu satuan maka akan menurunkan Kinerja Guru sebesar 1,126 satuan

Terdapat pengaruh positif dan

p.ISSN: 2407-800X e.ISSN: 2541-4356 
signifikan variabel disiplin kerja terhadap kinerja guru pada SMPN 1 Pangkalan. Dimana diperoleh tingkat signifikan lebih kecil dari alpha $(0,000<0,05)$. Hal tersebut membuktikan bahwa disiplin kerja bertujuan untuk mempegaruhi aktivitas para guru sehingga dapat mencapai tujuan bersama yang dirancang untuk memberikan manfaat individu dan organisasi. Ini berarti dusiplin kerja yang baik dapat meningkatkan Kinerja guru pada SMPN 1 Pangkalan.Selain itu juga didapat nilai koefisien regresi dari variabel disiplin kerja sebesar 0,334 Artinya jika terjadi peningkatan nilai disiplin kerja sebesar satu satuan maka akan meningkatkan Kinerja Guru sebesar 0,334 satuan. Demikian juga sebaliknya jika terjadi penurunan nilai disiplin kerja sebesar satu satuan maka akan menurunkan Kinerja Guru sebesar 0,334 satuan.

Secara bersama-sama terdapat pengaruh yang signifikan antara, Tingkat Pendidikan, Motivasi Kerja, dan Disiplin Kerja terhadap Kinerja Guru pada SMPN 1 Pangkalan. Tingkat Pendidikan, Motivasi Kerja, dan Disiplin Kerja secara bersamasama berpengaruh terhadap Kinerja Guru. Kontribusi Tingkat Pendidikan, Motivasi Kerja, dan Disiplin Kerja terhadap Kinerja Guru terlihat dari adjusted $\mathrm{R}^{2}$ diperoleh nilai koefisien sebesar 0,893 atau $89,3 \%$. Artinya adalah Tingkat Pendidikan, Motivasi Kerja, dan Disiplin Kerja proporsinya secara simultan menjelaskan pengaruh terhadap Kinerja Guru sebesar 89,3\%, sedangkan $10,7 \%$ ditentukan oleh faktor lain. faktor faktor lain itu bisa berupa Kompensasi, pelatihan kerja, kepemimpinan kepala sekolah, gaya kepemimpinan, dll. Jadi dapat disimpulkan bahwa Tingkat Pendidikan, Motivasi Kerja, dan Disiplin Kerja yang baik dapat meningkatkan Kinerja Guru pada SMPN 1 Pangkalan.

\section{SIMPULAN}

Berdasarkan analisa data,
interpresentasi hasil penelitian, dan
pembahasan yang telah disampaikan
sebelumnya maka dapat dikemukakan
beberapa kesimpulan dari hasil penelitian ini Jurnal Daya Saing (Vol. 4, No. 1 Feb 2018) sebagai berikut: Hasil penelitian menunjukkan terdapat pengaruh positif tetapi tidak signifikan variabel Tingkat Pendidikan terhadap Kinerja Guru pada SMPN 1 Pangkalan. Dimana diperoleh tingkat signifikan lebih besar dari alpha $(0,722>0,05)$. Hasil penelitian menunjukkan terdapat pengaruh positif dan signifikan variabel Motivasi Kerja terhadap Kinerja Guru pada SMPN 1 Pangkalan. Dimana diperoleh tingkat signifikan lebih kecil dari alpha $(0,000<0,05)$. Hasil penelitian menunjukkan terdapat pengaruh positif dan signifikan variabel Disiplin Kerja terhadap Kinerja Guru pada SMPN 1 Pangkalan. Dimana diperoleh tingkat signifikan lebih kecil dari alpha $(0,000<0,05)$. Hasil penelitian menunjukkan Secara bersama-sama terdapat pengaruh positif dan signifikan antara, Tingkat Pendidikan, Motivasi Kerja, dan Disiplin Kerja terhadap Kinerja Guru pada SMPN 1 Pangkalan. Tingkat Pendidikan, Motivasi Kerja, dan Disiplin Kerja secara bersama-sama berpengaruh terhadap Kinerja Guru terlihat dari nilai Adjusted R Square sebesar 89,3\% (tabel 4.22) dan nilai $F$ sebesar 89.610, sign 0.000 .

\section{DAFTAR RUJUKAN}

Mangkunegara, Anwar Prabu, (2015). Manajemen Sumber Daya Manusia Perusahaan. Bandung: PT Remaja Rosdakarya.

Sunyoto, Danang, (2012). Teori, Questioner, Dan Analisis Data Sumber Daya Manusia (Praktik Penelitian). Yogyakarta: CAPS (Center For Academic Publishing Service)

Sedarmayanti, (2015). Manajemen Sumber Daya Manusia, Reformasi Birokrasi Dan Manajemen Pegawai Negeri Sipil. Bandung: Refika Aditama. 
Nuruni, Tri, (2014). Pengaruh Tingkat Pendidikan Dan Pengalaman Kerja Terhadap Kinerja Guru Pai Sd Negeri Di Kecamatan Sidoharjo Kabupaten Sragen. Surakarta: Pascasarjana Institut Agama Islam Negeri Surakarta

Handono, Istu, (2015). Pengaruh Kedisiplinan Dan Motivasi KerjaTerhadap Kinerja Guru Ips. Jurnal: JJPI Jilid 7 Nomor 10.

Sutrisno, Edy, (2009). Manajemen Sumber Daya ManusiaEdisi 1. Jakarta: Kencana PrenadaMediaGroup

Anwar Sanusi, (2011), Metode Penelitian Bisnis, Salemba Empat, Jakarta
Sugiyono dan Rahadhini, MD, (2011). Pengaruh Pendidikan Pelatihan, Motivasi Kerja, Dan lingkungan Kerja Terhadap Kinerja Guru. Jurnal Manajemen Sumber Daya Manusia Vol. 5 No. 1: Fakultas Ekonomi Universitas Slamet Riyadi Surakarta

Dwi Priyatno, (2008). Mandiri Belajar SPSS. Mediakom: Yogyakarta

Riskawati, (2013). Uji Validitas Dan Realibilitas. Statistika Pendidikan: http://statistikapendidikan.com 